\title{
Kewenangan Istri dalam Rumah Tangga Sistem Semendo Ambil Anak dalam Perspektif Hukum Islam dan Hukum Positif
}

\author{
Dr. Zurifah Nurdin, M.Ag. \\ zurifah@iainbengkulu.ac.id \\ IAIN Bengkulu \\ Jl. Raden Fatah Pagar Dewa Kota Bengkulu
}

\begin{abstract}
Authority of Wives in Semendo System Households Take Children in Perspective of Islamic Law and Positive Law. Marriage The semendo system is marriage by making a man a son-in-law and heir to him and this man does not give honest to the bride even he is an honest recipient. The offspring of the semnedo system are related to their wives and siblings and do not have any power either in property or in their children. The position of the wife is higher than that of the husband so that the wife has power over everything. Husbands who have carried out their family obligations and are made only as shields and symbols of leadership in their households are not in line with maquashid as-syari' ah and ignore al-'urf al-sh -hah. In the theory of husband's rights and obligations, what is obligatory husband is the wife's right and what is the duty of the wife is the husband's right. Providing a living to the family is the obligation of the husband and earning a living from the husband is the right of the wife. if a husband has fulfilled his family's obligation, the husband has the right to become a leader who has authority.
\end{abstract}

Keywords: Marriage System, Semendo, Maqũshid as-syari’'ah, Al-'urf Al-shihah

Abstrak: Perkawinan Sistem semendo adalah perkawinan dengan menjadikan
seorang laki-laki sebagai menantu dan ahli waris baginya dan laki-laki ini tidak
memberikan jujur kepada pihak mempelai perempuan bahkan dia adalah penerima
jujur. Anak keturunan dari sistem semnedo ini masuk kekerabatan istri dan
sibapak tidak mempunyai kekuasaan apaun baik dalam harta maupun terhadap
anak-anaknya. Posisi isteri lebih tinggi dari suami sehingga isteri mempunyai 
kuasa atas segalanya. Suami yang telah menjalankan kewajiban nafkah bagi keluarganya dan dijadikan hanya sebagai tameng dan simbol kepemimpinan dalam rumah tangganya tidak sejalan dengan maqũshid as-syarı̈'ah dan mengabaikan al'urf al-shihah. Dalam teori hak dan kewajiban suami dijelaskan bahwa apa yang menjadi kewajiban suami merupakan hak istri dan apa yang menjadi kewajiban istri merupakan hak suami. Memberikan nafkah pada keluarga adalah kewajiban suami dan mendapatkan nafkah dari suami merupakan hak isteri. jika seorang suami telah memenuhi kewajiban nafkah bagi keluarganya, maka suami berhak menjadi pemimpin yang mempunyai otoritas.

Kata Kunci: Sistem Perkawinan, Semendo, Maqãshid as-syarĭ'ah, Al-'urf Alshihah

\section{A. Pendahuluan}

Perkawinan dalam arti perikatan adat adalah perkawinan yang mempunyai akibat hukum terhadap adat yang berlaku dalam masyarakat. Dalam persepektif Sosiologis, perkawinan merupakan kegiatan penyatuan kehidupan antara laki-laki dengan seorang perempuan dalam sebuah institusi keluarga dalam masyarakat. A. Van Gennep menjelaskan bahwa perkawinan adalah merupakan upacara-upacara yang melambangkan peralihan atau perubahan status dari mempelai berdua, yang asalnya hidup terpisah, setelah melaksanakan upaca perkawinan menjadi hidup bersatu kehidupan bersama sebagai suami istri. Semula mereka merupakan warga keluarga orang tua mereka masing-masing, setelah perkawinan mereka berdua merupakan keluarga sendiri, suatu keluarga baru yang berdiri sendiri dan mereka pimpin sendiri. ${ }^{1}$ Sedangkan perkawinan menurut Antropologis, merupakan suatu transaksi menurut adat kebiasaan untuk mendapatkan legitimasi dari masyarakat. ${ }^{2}$

Legitimasi atau pengakuan terhadap perkawinan menghasilkan suatu jalinan suami istri, 
Kewenangan Istri dalam Rumah Tangga Sistem Semenda Ambil Anak dalam Perspektif Hukum Islam dan Hukum

kontrak yang menimbulkan hak dan kewajiban secara terus menerus dan menimbulkan ikatan emosional dan sosial. Dalam ini penulis akan menjelaskan bagaimana posisi perempuan dalam sistem perkawinan semendo persepektif Hukum Islam,

\section{A. Pembahasan}

\section{Perkawinan Semendo}

Perkawinan

Sistem

Semendo merupakan bentuk perkawinan mengambil anak maksudnya adalah mengangkat/menjadikan

seseorang sebagai anak, seorang anak laki-laki diambil untuk suami dari seorang gadis, gadis tersebut adalah berhukum patrilineal, dengan tujuan supaya laki-laki itu menjadi anaknya sendiri dan anak yang dilahirkan menjadi keturunan dari klan istrinya. ${ }^{3} \mathrm{Kalau}$ jujur tidak dibayar, di Gayo; anggap, Sumatra Selatan disebut semendo ambil anak, angkon, dalam bahasa Belanda disebut sebagai inlijf huwelijik, kadangkadang suami yang menerima jujur ${ }^{4}$ sehingga ia lepas dari klannya sendiri, terdapat di Sumatera Selatan.

Adapun fungsi pemberian jujur adalah;

a. Secara yuridis, pemberian jujur adalah untuk mengubah status keanggotaan calon pengantin wanita.

b. Secara ekonomi, membawa pergeseran dalam harta kekayaan dan

c. Secarah sosial, penyerahan jujur mempunyai arti pihak si wanita mempunyai kedudukan yang dihormati.

Perkawinan jujur terdapat pada masyarakat hukum yang mempertahankan garis keturunan atau kebapakan (patrilinear) misalnya, Gayo, Batak, Nias, Lampung, Bali, Timor, dan Maluku, pada masyarakat Tapanuli (Batak) pembayaran jujur disebut dengan istilah boli, tuho, perunjuk, pangoli, sinamot. Di Nias: disebut dengan istilah beuli aiha. Gayo: unjuk, Lampung; seroh, Timor: belis 
Maluku beli atau wilin dan Bali; patunkunluh. Perkawinan jujur mengandung ketentuan pokok sebagai berikut:

a. Perkawinan dilakukan dari seorang dari luar marganya (clan)

b. Perkawinan bersifat asimentris

c. Istri dilepaskan dari lingkungan famili keluarga marga sendiri

d. Kepada istri dan family diberikan sejumlah uang dan barang jujur

e. Istri dimasukkan dalam lingkungan kerabat suaminya

f. Istri mengikuti dan menetap dalam lingkungan kerabat suaminya

g. Hak dan kekuasaan dalam lingkungan keluarga kerabat dan derajat sosial suami lebih tinggi dari istrinya

h. Anak-anak masuk kerabat suami

i. Suami menguasai harta kekayaan, tidak ada harta bersama. $^{5}$

Pemberian/pembayaran yang jujur dimaksudkan untuk melepas istri dari lingkungan kerabatnya dan pindah kelingkungan kerabat suaminya, maka dengan perpindahannya istri kekerabat suami, maka pada kekerabatan istri terjadi kevakuman magis. Karena kepakuman itu dapat diperbaiki dengan menyerahkan pembayaran jujur sebagai pengganti atau pengisi kevakuman itu, pemberian jujur dapat diartikan sebagai suatu pemberian kedalam suasana religius -magis guna memelihara tetapnya keseimbangan hubungan kedua belah pihak, jadi bukan pembayaran sebagai harga pembelian si istri itu, adalah pendapat yang keliru. Pembayaran biasanya dilakukan menjelang perkawinan secara tunai, tetapi ada kemungkinan terjadi jujur (mas kawin) dibayar dikemudian hari, pada masyarakat Batak apabilah perkawinan belum dilakukan dengan adat Nagok, 
Kewenangan Istri dalam Rumah Tangga Sistem Semenda Ambil Anak dalam Perspektif Hukum Islam dan Hukum

artinya belum lunas atau tuntas pemberian jujur atau boli atau tuhor tersebut. Selama belum melaksanakan boli dan semacamnya tersebut, maka anaknya menjadi terhalang melaksanakan perkawinannya.

a. Perkawian mengambil anak (Inliijf Huwelijk)

Artinya seorang anak lakilaki diambil untuk seorang gadis, gadis tersebut adalah berhukum patrineal. Mengambil anak adalah supaya menantu laki laki itu menjadi anaknya sendiri dan anak yang dilahirkan menjadi keturunan dari klan istrinya (mertua) kalau jujur tidak dibayar, di Gayo, Sumatra Selatan disebut semendo ambil anak, angkon, kadang-kadang suami yang menerima jujur sehingga ia lepas dari klannya sendiri, terdapat di Sumatera Selatan.

Sedangkan pengertian perkawinan mengambil anak dalam masyarakat yang bersistem matrilineal adalah mengambil anak laki-laki sebagai menantu untuk menjadi ahli waris mertuanya dan laki-laki ini tidak memberikan jujur kepada pihak mempelai perempuan akan tetapi silaki-laki adalah penerima jujur, yang melamar adalah pihak perempuan ${ }^{6}$. Anak-anak dari keturunannya masuk keluarga istrinya dan sibapak tidak mempunyai kekuasaan terhadap anakanaknya. Adapun ketentuanketentuan pokok pada perkawinan semedo adalah sebagai berikut.

1) Istri tidak lepas dari familinya sendiri dan suamipun juga tidak lepas dari kerabatnya suami diterima sebagai urang semedo

2) Istri tetap pada lingkungan suaminya sendiri suami tidak harus menetap mengikuti suaminya.

3) Hak dan kekuasaan istri dalam keluarga dan kedudukannya lebih tinggi dari pada suami, suami bukan kepala keluarga.

4) Anak-anak masuk kerabat istri (ibunya) 
5) Istri menguasai harta kekayaan, tidak ada harta bersama.

Adapun pengertian perkawinan semendo ambil anak dalam pasal kelima (5) buku Sending Delapan ${ }^{7}$ adalah perkawinan seorang laki-laki yang tidak sama sekali memberikan harta/uang kepada pihak perempuan, jika terjadi perceraian anak, semua harta dan hutang jatuh pada bapak yang mengangkatnya menjadi anak (mertuanya). Dan dia tidak mendapatkan apapun, kecuali pakaian yang dipakai.

Dari informasi tentang pengertian mengambil anak ini dapat difahami bahwa perkawinan mengmbil anak dalam masyarakat patrineal adalah suatu perkawinan antara seorang laki-laki dengan seorang gadis yang mana si laki-laki tanpa membayar jujur, atau jujur hutang kepada pihak perempuan, yang melamar lakilaki dan, anak laki- laki ini tadi diangkat menjadi anaknya sendiri dan anak yang dilahirkan menjadi keturunan dari pihak istri, serta tidak dijadikan sebagai ahli waris. Sedangkan semenda ambil anak dalam masyarakat matrilineal adalah perkawinan seorang laki-laki terhadap gadis, yang juga si laki-laki tidak memberikan jujur, yang melamar pihak perempuan dan dijadikan sebagai ahli waris. Anak-anak yang dilahirkan masuk keluarga istri, dan suami (si bapak) tidak mempunya kekuasaan terhadap anak.

Sedangkan sebutan (istilahistilah) perkawinan ambil anak bagi masyarakat berhukum patrilineal. Adalah di GayoAnggap, Sumatera Selatantambik anak, ambik anak, di Lampung Ngakuk ragah, di Balinyentane-di dan inliijf huwelijk Belanda. Bagi masyarakat berhukum matrilineal istilah yang digunakan dalam perkawinan mengambil anak adalah Anggap di Gayo, semendo ambil anak, nongkon, campur sumbai di Sumatera Selatan, kawin ambil piara di Ambon, nyeburin di Bali dan inlijk huwelijk dalam bahasa Belanda. ${ }^{8}$

\section{Bentuk-bentuk Perkawinan Semendo:}


Kewenangan Istri dalam Rumah Tangga Sistem Semenda Ambil Anak dalam Perspektif Hukum Islam dan Hukum

Positif

a. Semedo rajo-rajo

Yaitu suami istri berkedudukan sama baik dipihak istri maupun suami.

b. Semendo bebas:

Suami menetap pada kerabatnya ia hanya urang semedo.

c. Semendo menetap

Artinya suami mengikuti kediaman istri.

d. Semendo menunggu,

Suami istri berkediaman ditempat kerabat istri selama menunggu adik istri sampai dapat mandiri/sampai tugas pertanggungjawabannya terhadap keluarga mertua selesai diurusnya

e. Semenda nangkit (ngangkit), Suami menjadikan istri untuk menjadikan penerus keturunan pihak suami karena ibunya tidak mempunyai anak perempuan. Sehingga suami istri ini nantinya akan menguasai harta kekayaan dan meneruskan keturunannya. Semenda ngangkit ini kebalikan dari perkawinan semenda ambil anak. ${ }^{9}$

f.Semendo anak gadang,

Suami tidak menetap ditempat istrinya melainkan datang sewaktu-waktu lalu kemudian pergi (sementara)

g. Semenda bertandang

Artinya suami tidak bertempat tinggal yang sama,

h. Semenda ambil anak,

Artinya mengambil anak laki-laki sebagai menantu untuk menjadi ahli waris mertua.

i. Semenda beradat,

Pihak pria membayar uang kerabat kepada kerabat wanita menurut martabat adatnya.

j. Semenda tidak beradat,

Artinya pihak pria tidak membayar adat karena semua biaya ditanggung pihak wanita. 10

Kedatangan seseorang kedalam lingkungan suatu keluarga akibat perkawinan dinamakan semendo, sebab prinsip keturunan dalam suku bangsa Melayu sudah tidak 
menentukan ikatan khusus, bila seseorang akan melaksanakan perkawinan biasanya yang dipilih adalah keseimbangan hak keturunan antara laki-laki dan perempuan. Adapun semendo dalam adat suku Melayu ada tiga macam, ${ }^{11}$ yaitu:

a. Semendo bleket

Artinya pihak perempuan setelah kawin sudah menjadi milik keluarga laki-laki dan tidak diperbolehkan berhubungan langsung dengan keluarganya lagi tanpa seijin suaminya atau keluarga suami.

b. Semendo ta abik anak

Artinya pihak laki-laki setelah kawin sudah menjadi milik keluarga perempuan dan tidak diperbolehkan berhubungan langsung dengan keluarganya lagi tanpa seijin istrinya atau keluarga istri. Bila terjadi perceraian maka si laki-laki wajib meninggalkan segala hasil usaha selama perkawinan pada keluarga istri dan mengganti segala biaya semasa perkawinan untuk istri. c. Semendo rajo-rajo

Artinya masing-masing mempunyai hak dan kewajiban yang sama dalam perkawinan dan sesudahnya.

Selain yang tersebut diatas ada satu macam lagi sistem perkawinan yang mempunyai maksud yang sama dengan perkawinan ambil anak, yaitu perkawinan semendo bayar hutang. ${ }^{12}$ Perkawinan semendo bayar hutang adalah perkawinan seorang laki-laki dengan seorang gadis, sang laki-laki yang akan melaksanakan perkawinan mempunyai hutang pada orang tua si gadis. Hutangnya dianggap lunas dan diapun diangkat jadi anak. Bentuk perkawinan semendo pada masyarakat Lampung ada beberap macam, ${ }^{13}$ yaitu;

a. Semenda Lepas.

Di daerah Lampung pesisir yang pada umumnya beradat peminggir, ada istilah semenda lepas yang artinya setelah terjadi perkawinan maka suami melepaskan hak dan kedudukan dipihak 
Kewenangan Istri dalam Rumah Tangga Sistem Semenda Ambil Anak dalam Perspektif Hukum Islam dan Hukum

kerabatnya dan masuk kedalam kerabat istri. Bentuk ini sama dengan perkawinan Cambur atau perkawinan nangkon yang juga tidak lain adalah sama dengan perakwinan semenda ambil anak (inlijf Huwelijk) dimana suami tidak mempunyai kekuasaan apa-apa.

b. Semendo tegak-tegi

Artinya seorang anak perempuan dikawinkan dengan pria dimana pria itu diambil dari anggota keluarga pihak perempuan (ibu) dan menantu ini sekaligus diangkat sebagai anak oleh mertuanya, sehingga mempunyai kedudukan sebgai ahli waris dari mertuanya.

c. Semendo ambil (tambik)anak,

Perkawinan ini hampir sama dengan perkawinan semendo tegak tegi namun dalam perkawinan ini pengantin laki-laki yang dijadikan menantu bukan dari pihak keluarga. Diangkat jadi anak dan menjadi ahli waris dari mertuanya.

d. Kawin semendo djengmirul
Pada bentuk perkawinan ini kedudukan suami adalah sebagai wali terhadap istri dan anak-anaknya, sehingga suami dalam semua persoalan hukum dari keluarga mertuanya hanya bertindak sebagai wali.

e. Kawin semendo meminjam(meminjam jago) yaitu perkawinan yang menempatkan laki-laki hanya mempunyai kedudukan sebagai suami saja yakni untuk menolong keluarga yang bersangkutan untuk memperoleh anak-anak.

\section{Analisa Hukum Islam dan} Hukum Positif Terhadap Kewenangan Isteri

Secara subtansi perkawinan semendo isteri memiliki derajat yang lebih tinggi, sebagai penguasa harta, anak-anak bernasab keibu serta dan kepala keluarga , bagaikan "majikan" dari suaminya, kondisi ini dikarenakan suami bukanlah yang melamar, bukan pula pemberi mahar, bukan wali bagi anak keturunannya, pencari nafkah, ahli waris dari orangtua isterinya, dan jika 
terjadi perceraian si suami hanya membawa pakaian yang melakat pada dirinya. Struktur kepemimpinan utama dalam keluarga sistem semendo ini ada pada isteri sedangkan suami pekerja saja.

Hukum Islam dan peraturan perundangundangan yang berlaku di Indonesia tentang perkawinan jelas menyatakan bahwa yang melamar dan yang memberikan mahar itu adalah laki-laki (calon suami/ keluarganyya). Islam memberikan perlindungan dan penghormati pada perempuan dengan diberikannya kepemilikan. Mahar merupaka pemberian wajib mempelai pria kepada calon mempelai wanita yang yang jumlah, bentuk dan jenisnya disepakati oleh kedua belah pihak. ${ }^{14}$ Pasal 31 Kompilasi Hukum Islam dinyatakan bahwa penentuan mahar berdasarkan atas kesederhanaan dan kemudahan yang dianjurkan oleh ajaran Islam.

Dalam firman Allah swt ${ }^{15}$ yang menyatakan bahwa mahar adalah fariihdatun (sebagai kewajiban yang harus dibayar suami untuk menjadi hak istri.

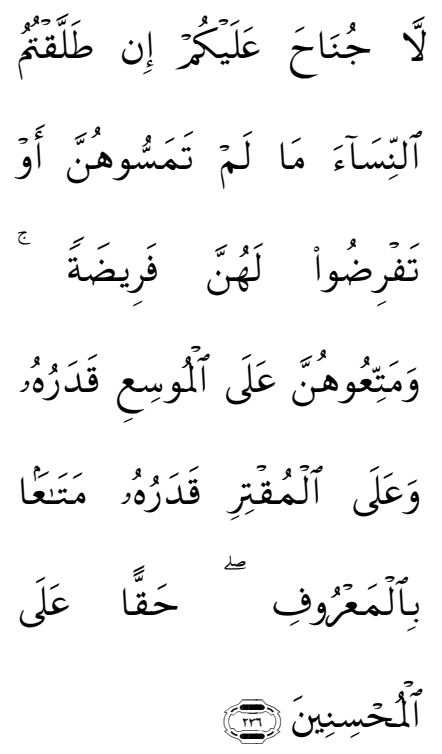

"Tidak ada kewajiban membayar (mahar) atas kamu, jika kamu menceraikan isteri-isteri kamu sebelum kamu bercampur dengan mereka dan sebelum kamu menentukan maharnya. dan hendaklah kamu berikan suatu mut'ah (pemberian) kepada mereka. orang yang mampu menurut kemampuannya dan orang yang miskin menurut kemampuannya (pula), Yaitu pemberian menurut yang patut. yang demikian itu merupakan ketentuan bagi orangorang yang berbuat kebajikan." 
Kewenangan Istri dalam Rumah Tangga Sistem Semenda Ambil Anak dalam Perspektif Hukum Islam dan Hukum

Adapun batasan mahar yang diberikan suami kepada istri para ulama juga memberikan komentarnya sebagai berikut;. Menurut Abu Hanifah dan Ashhabnya, serta golongan Al Itrah, bahwa sekurang-kurangnya mahar adalah sepuluh dirham atau yang seharganya. Sedangkan menurut Umar, Ibnu 'Abbas, Al Hasanul Bisri, Ibnu Musayyab, Rabiah, Al Auza'y, Ahmad, Ishaq, As Syafi'i, bahwa sekurang-kurangnya kadar mahar, ialah yang sah dijadikan harga atau upah. 16

Menurut penulis mahar itu tidak ada batasan minimal ataupun maksimal, mahar boleh berupa apa saja asal mempunyai nilai dan bermanfaat bagi sang istri serta sang istri ridho akan pemberian itu. Istri tetap berhak menerima mahar walaupun suaminya meninggal sebelum dukhul dan khilwat, sesudah akad, walaupun kadar mahar belum ditentukan. Mahar boleh segerahkan dan boleh juga ditangguhkan, atau baru dibayar sebagiannya disegerahkan dan sebagianya lagi ditangguhkan, sesuai dengan kebiasaan dan tradisi yang dianut pihak perempuan. Namun menurut petunjuk dari hadis, sebaiknya memberikan sebagian mahar qobladukhul, walaupun yang demikian itu tidak dimestikan, karena memberikan sebagian mahar, apalagi memberikan semuanya, adalah merupakan tanda kecintaan antara suami dan istri. $^{17}$

Peraturan perundangundangan yang ada di Inonesia juga mengatur akan mahar, ${ }^{18}$ didalamnya dijelaskan bahwa calon mempelai pria wajib membayar mahar kepada calon mempelai wanita yang jumlahnya, bentuk dan jenisnya disepakati oleh kedua belah pihak dan batasan mahar atas kesederhanaan dan kemudahan yang dianjurkan oleh ajaran Islam.

Ditinjau dari segi aspek soaiologi (kontekstual) di Indonesia dan juga di negara Muslim lainnya juga dipahami bahwa mahar merupaka kewajiban bagi laki-laki, dan 
Jurnal Hawa Vol. I No. I Januari-Juni 20IG

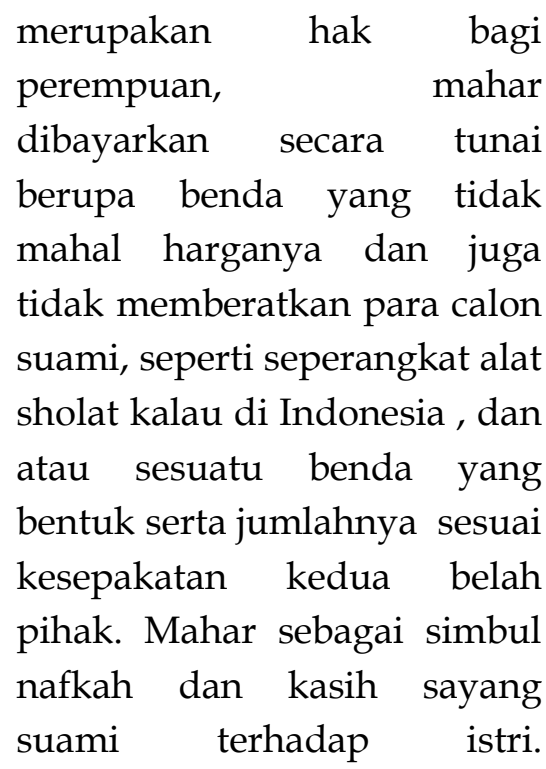

Kewajiban pemberian mahar oleh laki-laki kepada perempuan dijelaskan oleh Allah swt, sebagaimana firmanNya ${ }^{19}$ berikut;

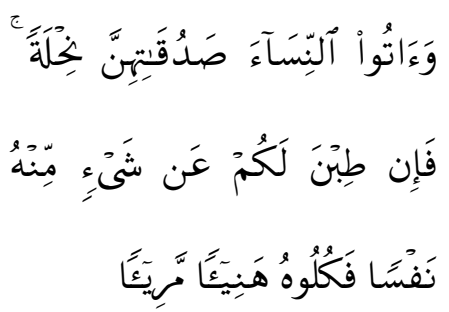

"Berikanlah

maskawin

(mahar) kepada wanita (yang kamu nikahi) sebagai pemberian dengan penuh kerelaan. kemudian jika mereka menyerahkan kepada kamu sebagian dari maskawin itu dengan senang hati, Maka makanlah (ambillah) pemberian itu (sebagai makanan) yang sedap lagi baik akibatnya.

Lalu dalam Hadis Nabi Saw, 20

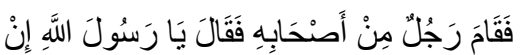

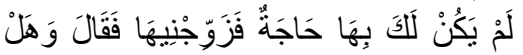

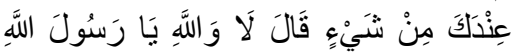

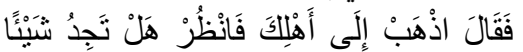

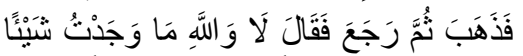

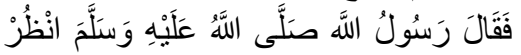

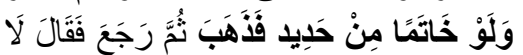

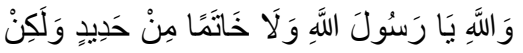

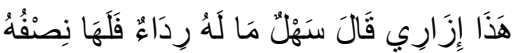

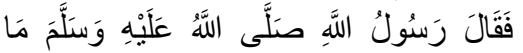

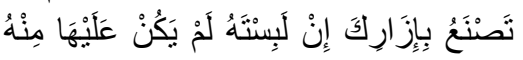

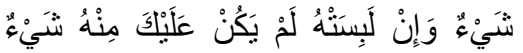

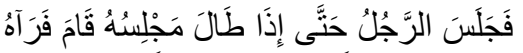

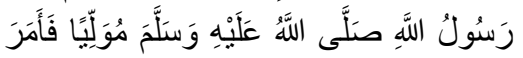

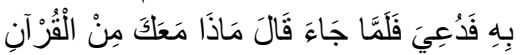

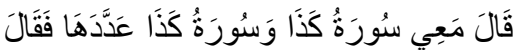

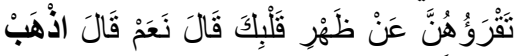

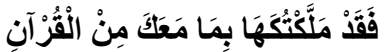

Tiba-tiba seorang sahabat berdiri dan berkata, "Wahai Rasulullah, jika Anda tidak berhasrat kepada wanita itu maka nikahkanlah aku dengannya." Maka beliau pun bertanya: "Apakah kamu mempunyai sesuatu (untuk dijadikan mahar)?" sahabat itu menjawab, "Tidak, demi Allah wahai Rasulullah." Beliau bersabda: "Pergilah kepada keluargamu, dan lihatlah apakah ada sesuatu." 
Kewenangan Istri dalam Rumah Tangga Sistem Semenda Ambil Anak dalam Perspektif Hukum Islam dan Hukum

Positif

Laki-laki itu pun pergi dan kembali seraya berkata, "Tidak, demi Allah wahai Rasulullah, aku tidak mendapatkan sesuatu." Beliau bersabda lagi: "Lihatlah, meskipun yang ada hanyalah cincin dari besi." Laki-laki itu pergi laki kemudian kembali dan berkata, "Tidak, demi Allah wahai Rasulullah meskipun hanya cincin besi. Akan tetapi aku mempunya kain ini." Sahl berkata; Ia tidak memiliki kain kecuali setengah. Maka Rasulullah shallallahu 'alaihi wasallam pun bersabda: "Apa yang dapat kamu lakukan dengan kainmu itu. Jika kamu memakainya maka ia tidak akan kebagian, dan jika ia memakainya maka tidak akan kebagian." Akhirnya laki-laki itu duduk hingga lama, lalu ia beranjak. Kemudian Rasulullah shallallahu 'alaihi wasallam pun melihatnya hendak pulang. Maka beliau memerintahkan seseorang agar memanggilnya. Ketika laki-laki itu datang, beliau bertanya: "Surat apa yang kamu hafal dari Al Qur'an." Ia berkata, "Yaitu surat ini." Ia menghitungnya. Beliau bersabda: "Apakah kamu menghafalnya dengan baik?" laki-laki itu menjawab,"Ya." Akhirnya beliau bersabda: "Sesungguhnya aku telah menikahkanmu dengan wanita itu dengan mahar hafalan $\mathrm{Al}$ Qur`anmu.

Mahar yang diberikan oleh laki-laki (suami) menjadi hak para perempuan sebagaimana yang telah ditetapkan dan tidak boleh diganti dengan imbalan apapun. Namun jika sang istri memberikannya dengan ikhlas tanpa paksaan, maka memanfaatkannya tidak menjadi masalah, Allah Swt berfirman. ${ }^{21}$

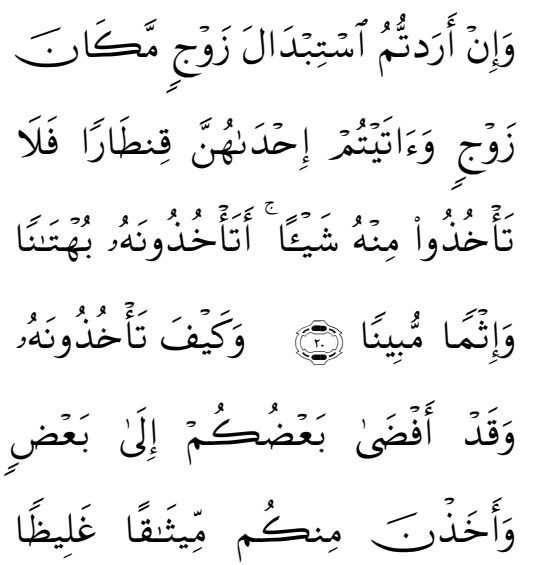

"Dan jika kamu ingin mengganti isterimu dengan isteri yang lain, sedang kamu telah memberikan kepada seseorang di antara mereka harta yang banyak, Maka janganlah kamu mengambil 
Jurnal Hawa Vol. I No. I Januari-Juni 2019

kembali dari padanya barang sedikitpun. Apakah kamu akan mengambilnya kembali dengan jalan tuduhan yang Dusta dan dengan (menanggung) dosa yang nyata ?Bagaimana kamu akan mengambilnya kembali, Padahal sebagian kamu telah bergaul (bercampur) dengan yang lain sebagai suami-isteri. dan mereka (isteri-isterimu) telah mengambil dari kamu Perjanjian yang kuat."

Mahar itu mencerminkan kasih sayang suami terhadap istrinya dan merupakan simbol kesediaan suami hidup bersama istri dan sanggup berkorban untuk kesejahteraan rumah tangga dan keluarganya, mahar juga merupakan penghormatan seorang suami terhadap istri.

Dalam firman Allah swt memang telah diinformasikan kepada umat Islam bahwa suami berkewajiban memberikan nafkah, pakaian dan perlindungan kepada istri dan anak-anaknya menurut ukuran yang makruf.22 Firman Allah swt yang dimaksud adalah,, 23

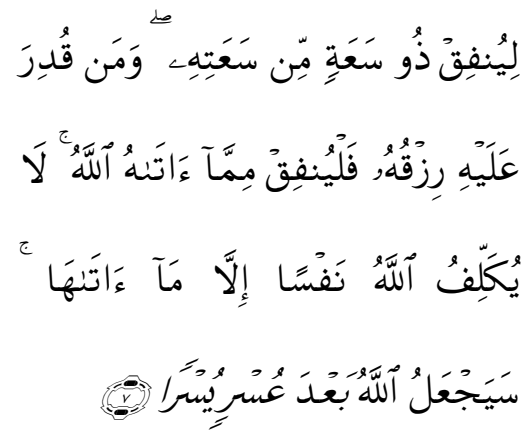

"Hendaklah orang yang mampu memberi nafkah menurut kemampuannya. Dan orang yang disempitkan rezkinya hendaklah memberi nafkah dari harta yang diberikan Allah kepadanya. Allah tidak memikulkan beban kepada seseorang melainkan sekedar apa yang Allah berikan kepadanya. Allah kelak akan memberikan kelapangan sesudah kesempitan."

Kedudukan suami sebagai pemimpin, penguasa dalam harta bagi istri dan anakanaknya dan atau sebagai pelaksana segala urusan wanita dikarenakan suami (laki-laki) mempunyai kelebihan baik kelebihan bersifat hakiki, seperti kemampuan berfikir dan kemampuan fisik, maupun kelebihan bersifat syar'i seperti kelebihan dalam menerima warisan. 
Kewenangan Istri dalam Rumah Tangga Sistem Semenda Ambil Anak dalam Perspektif Hukum Islam dan Hukum

Positif

Kepemimpinan laki-laki sebagaimana dalam firman Allah swt ${ }^{24}$ mengandung faktor yang bersifat fitri yang mencakup kekuatan fisik dan ketenangan akal dan juga mengandung faktor yang bersifat kasbi (usaha) yang mencakup tanggung jawab membayar mahar dan nafkah keluarga sehingga istri dapat menyelesaikan tugas mengandung melahirka, menyusui, dengan baik dan benar. ${ }^{25}$ Dalam Buku Kitab Hukum Perdata pasal 105 dijelaskan bahwa suami adalah kepala dalam persatuan suami istri, setiap suami harus mengemudikan urusan harta kekayaan milik pribadi istrinya, kecuali ada perjanjian lainya. Pasal 106 dinyatakan bahwa setiap istri harus tunduk dan patuh pada suaminya. ${ }^{26}$

Oleh karena itu kepemilikan dan kekuasaan harta oleh suami dikarenakan suami mempunyai kepemilikan terhadap nafkah. Untuk itu seorang suami bisa menjadi kepemilikan dan kekuasaan harta karena kepemilikan terhadap nafkah harus memenuhi syarat. ${ }^{27 K e n d a t i \quad s u a m i ~}$ berkewajiban mencari dan memberikan nafkah kepada istrinya, dan tidak ada dalil yang melarang sang istri untuk mencari nafkah bersama-sama suami. Namun jika istri mencari nafkah bersama-sama dengan suami dalam rangka memenuhi kebutuhan rumah tangga, maka istri tidak mempunyai kewajiban sebagaimana suami. Karena istri berperan hanya demi kemaslahatan dan kelanggengan rumah tangga atau kehidupan rumah tangga. Seandainya kebutuhan semakin hari semakin meningkat, maka keikutan istri menanggung nafkah keluarga berdasarkan kerelaannya dan tidak mempengaruhi ketentuan keharusan mencari nafkah bagi suami, karena yang menjadi pemimpin adalah laki-laki, sebagaimana Nash dan peraturan diatas. 


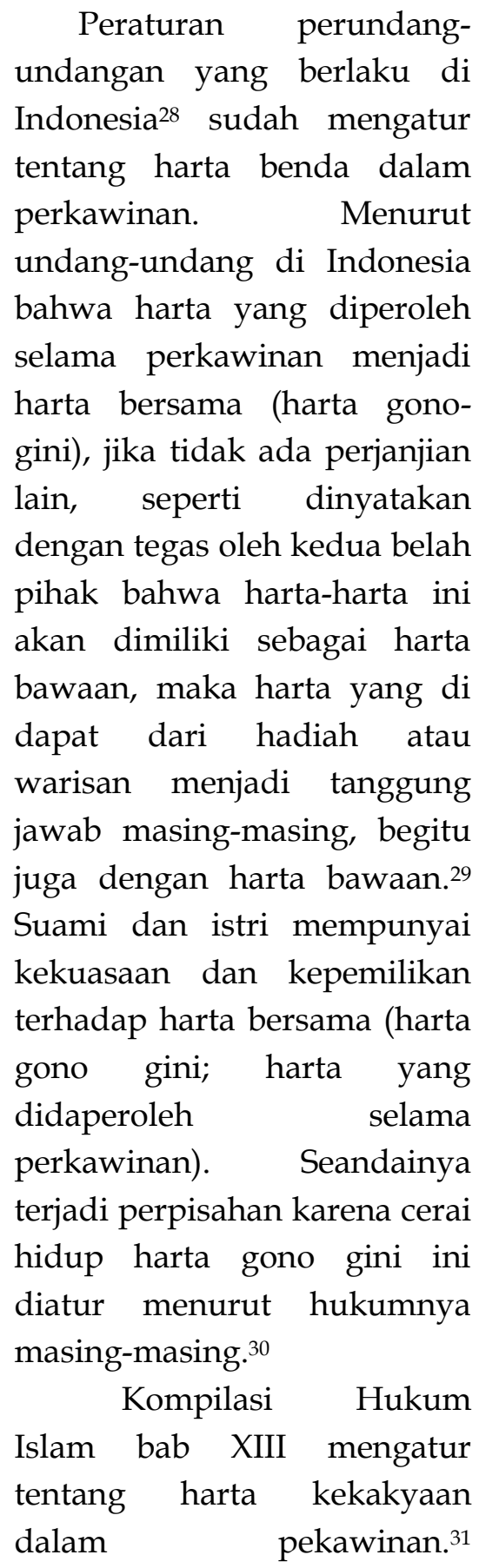

Dinyatakan bahwa harta bersama dalam perkawinan, namun keberadaanya tidak menutup kemungkinan adanya harta masing-masing, menyebutkan bahwa terhadap milik masing-masing tidak dikenal percampuran harta. Harta istri adalah harta istri, harta suami adalah harta suami. Dan dinyatakan juga bahwa harta bawaan dari masing-masing suami dan istri dan harta yang diperpleh masing-masing sebagai hadiah atau warisan adalah dibawah penguasaan masing-masing, sepanjang para pihak tidak menentukan lain dalam perjanjian perkawinan. Suami dan istri mempunyai hak sepenuhnya untuk melakukan perbuatan hukum atas harta masing- masing, berupa hibah, hadiah, sodaqah atau yang lainya. Pada pasal 88 nya dinyatakan juga apabila terjadi perselisihan antara suami istri tentang harta gono-gini, maka penyelesaian itu diajukan kepada pengadilan agama. Dalam Undangundang no 1 tahun 1974 
Kewenangan Istri dalam Rumah Tangga Sistem Semenda Ambil Anak dalam Perspektif Hukum Islam dan Hukum Positif

terdapat peluang kepada pihak-pihak untuk menetapkan hukum lain dalam pembagian harta bersama jika terjadi perceraian, sementara dalam Kompilasi Hukum Islam menyarankan diselesaikan ke Pengadilan Agama, artinya harus diselesaikan sesuai hukum Islam, bahkan dinyatakan bahwa jika terjadi cerai mati, separoh dari harta bersama menjadi milik istri. ${ }^{32}$ Ini berarti sisa yang separoh lagi itulah yang menjadi warisan bagi kerabat ahli warisnya, tanpa mempertimbangkan mana disalah satu pihak yang aktip dalam mencari nafkah.

Sementara dalam undang-undang hukum perdata ditetapkan bahwa harta yang diperoleh selama perkawinan menjadi harta bersama atau percampuran harta kekayaan, serta harta bawaan masing-masing menjadi hak milik masingmasing. ${ }^{33}$ Suami sendiri yang harus mengurus harta kekayaan bersama, ia diperbolehkan menjual, memindah tangankan dan membebaninya tanpa campur tangan istri, kecuali dalam hal tercantum pada ayat ketiga pasal 40. ${ }^{34}$ Selaku hibah antara mereka yang masinh hidup, ia tak diperbolehkan menggunakan barang-barang persatuan baik barang-barang tak bergerak maupun bergerak dalam rangka untuk menyelenggarakan suatu kedudukan bagi anak-anak mereka. Istri juga tidak mempunyai hak untuk memanfaatkan, walau hanya hak pakai. Ini menunjukan bahwa semua harta dalam kekuasaan dan dimiliki suami. Dalam Kompilasi Hukum Islam disebutkan bahwa suami istri bertanggung jawab menjaga harta bersama, dan harta diri masing-masing, dan tidak melakukan tindakan apapun tanpa persetujuan salah satu pihak.

Pada prinsipnya
setiap pribadi punya
kemampuan sebagai penerima
hak dan melaksanakan
kewajiban (ahliyyah al wujub "


patut dikenakan kewajiban"). Begitu juga dipandang mampu bertindak terhadap harta miliknya (ahliyyah al ada' "patut melaksanakan kewajiban"). ${ }^{35}$ Namun jika belum atai tidak cakap untuk bertanggung jawab atas hartanya, maka perlu adanya jaminan dari wali. Ketidak cakapan itu menurut syar'i. Seperti belum baligh.

Adapun posisi suami dalam rumah tangga adalah sebagai kepala keluarga,36 suami adalah pembimbing terhadap istri dan anakanaknya, serta mengenai urusan rumah tangga diputuskan oleh suami. ${ }^{37}$ Posisi laki-laki sebagai pemimpin dijelaskan dalam Nash Al qur'an, sebagaimana firman Allah swt ${ }^{38}$

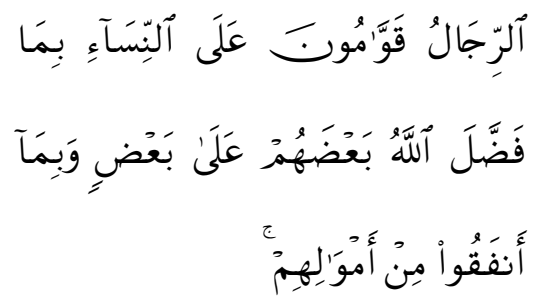

"Kaum laki-laki itu adalah pemimpin bagi kaum wanita, oleh karena Allah telah melebihkan sebahagian mereka (laki-laki) atas sebahagian yang lain (wanita), dan karena mereka (laki-laki) telah menafkahkan sebagian dari harta mereka."

Dan

dalam

peraturan perundangundangan Indonesia ${ }^{39}$ dinyatakan bahwa suami adalah kepala keluarga dan istri ibu rumah tangga, hak dan kedudukan istri adalah seimbang dengan hak dan kedudukan suami dalam kehidupan rumah tangga dan pergaulan hidup bersama dalam rumah tangga.Dengan demikian, jelas dapat dipahami bahwa suami dan istri merupakan pasangan yang bermitra dan sejajar yang karenanya mereka harus bekerja sama, saling melengkapi, saling menghargai dan saling menghormati. Abdul Wahab Khalaf, $40 \quad$ memberikan komentarnya dengan العادة محكمة "Adat adalah syari'ah muhkamah". Secara umum, pengertian adat adalah suatu perbuatan atau perkataan yang terus menerus dilakukan 
Kewenangan Istri dalam Rumah Tangga Sistem Semenda Ambil Anak dalam Perspektif Hukum Islam dan Hukum

Positif

oleh manusia lantara dapat diterimah akal dan secara kontinu manusia mau mengulangnya. ${ }^{41} \quad$ Adapun pengertian adat dalam istilah Ushul Fiqh adalah sesuatu yang telah saling dikenal oleh manusia dan mereka menjadikannya sebagai tradisi, baik berupa perkataan, perbuatan yang dilakukan berulang. ${ }^{42}$ Pengertian ini terambil dari firman Allah swt dalam surat al 'Araf:199. Adapun menurut Amir Lutfi 'urf adalah sesuatu yang dibiasakan dan diketahui (kearipan) oleh rakyat umum atau golongan masyarakat. ${ }^{43}$

Menurut Abdul Wahab 'urf terbagi dua yaitu 'urf shahihah dan 'urf fasidah. 'Urf shahihah adalah segala sesuatu yang sudah dikenal umat manusia dan tidak berlawanan dengan dalil syara', serta tidak menghalalkan yang haram dan tidak pula mengugurkan kewajiban.'Urfu shahihah merupakan suatu kebiasaan yang diterima oleh banyak orang , tidak bertentangan dengan syara', sopan santun dan budaya yang luhur. Hal ini sesuai dengan hadist Rasulullah Saw yang diriwayatkan oleh Ahmad.

قال رسول الله : مار أه المسلمون حسنا

فهو عند الله حسن رأه المسلمون سيئا

فهو عند الله سيئ. رواه أحمد الكسان

"Apa saja yang dipandang kaum muslimin merupakan kebaikan, maka ia disisi Allah juga merupakan kebaikan. Dan apa saja yang dipandang kaum muslimin merupakan keburukan, maka ia juga dipandang Allah keburukan." HR Ahmad ${ }^{44}$

'Urf yang shahilah yang dapat digunakan sebagai hujjah sedangkan yang fasid tidak. Hal ini untuk melihara hukum dan proses peradilan.45 Para mujtahid tentu harus melestarika atau memeliharanya. Segala sesuatu yang sudah saling dimengerti oleh manusia yang telah disepakati dan dinggap sebagai kemaslahatan serta tidak bertentangan dengan syara' untuk dijaga dan dilestarikan.'Urf-fasidah adalah segala sesuatu yang sudah dikenal oleh manusia tetapi berlawanan dengan 
syara' atau mengahalalkan yang haram dan mengugurkan kewajiban. Misalnya manusia saling mengerti untuk berbuat zhalim. 'Urf fasid merupakan kebiasaan yang berlaku disuatu tempat meskipun merata pelaksanaannya, namun bertentangan dengan syara', undang-undang dan juga sopan santun. Sesuatu kebiasaan yang sesuai dengan hukum syar'i dapat dijadikan hujjah. Sehingga 'urf yang fasid sudah pasti tidak dapat dijadikan hujjah.

B. Kesimpulan

Memposisikan isteri lebih berkuasa dan lebih tinggi dari suami sedangkan suami telah melaksanakan kewajiban nafkah, dan suami hanyalah sebagai tameng dan simbol kepemimpinan dalam keluarga seperti dalam sistem perkawinan semendo tidak mengandung maqãshid as-syar'̌ah sebab mengabaikan al-'urf al-shihah karena kepala rumah tangga dan pemimpin keluarga adalah hak suami yang telah melaksanakan kewajiban sebagai pencari nafkah.

Dan dalam teori hak dan kewajiban suami dan istri dijelaskan bahwa apa yang menjadi kewajiban suami merupakan hak istri dan apa yang menjadi kewajiban istri merupakan hak suami. Memberikan nafkah pada keluarga adalah kewajiban suami dan jika itu terlaksana maka seorang suami berhak mendapatkan kekuasaan dan derajat yang lebih tinggi di banding istri.

\section{Refrensi}

\begin{tabular}{l}
\hline Soerojo Wignjodipoero, \\
Pengantar dan Asas-asas Hukum \\
Adat,(Jakarta; Gunung Agung, 1984),.h. \\
$123{ }^{2}$ Gough dalam Roger M Keesing, \\
Cultural Antropology; A Contemporary \\
Perspektive, Antropologi Budaya: Suatu \\
Persektif Kontemporer, ter. R.G. \\
Soekadijo, Edisi kedua,. (Jakarta: \\
Erlangga, 1992),.h. 7 \\
Djamanat Samosir, Hukum Adat \\
Indonesia, Eksistensi dalam Dinamika \\
Perkembangan Hukum di Indonesia \\
(Bandung, Pt Nuansa Aulia, 2013), h. \\
284. Lihat juga, Talib Setiady, "Intisari \\
Hukum Adat Indonesia: dalam Kajian \\
Kepustakaan. (Bandung: \\
ALFABETA, 2013),h. 233-234 \\
4 Jujur merupakan pembayaran, \\
pemberian, dan atau maskawin. Bentuk
\end{tabular}


Kewenangan Istri dalam Rumah Tangga Sistem Semenda Ambil Anak dalam Perspektif Hukum Islam dan Hukum

Positif

konsekwensi dari perkawinan jujur adalah melanjutkan atau mempertahankan keturunan dari pihak laki-laki, perkawinan jujur dalam bahasa Belanda disebut Bruidschat Huwelijk. Adapun istilah-istilah teknis tentang jujur adalah; Batak -jujuran, unjung, mangoli, perunjuk dan sinamot, Sum Sel- jujur, di Nias-beuli niha, di Gayounjok, di Jawa-Tukon, di Lampung sero, segreh, daw adat, ngakuk, hibal. Di Pasemah- kule, tunak. Di Maluku-wilin, beli, di Rejang-beleket, di Palembang nuku, di Bali-patukun-luh. Dan dalanm bahasa Inodnesia Ganti. Talib Setiady, "Intisari Hukum Adat Indonesia: dalam kaji...Ibid,h. 231

5 Ahmad Sanusi, Pengantar Ilmu Hukum dan Pengantar Tata Hukum Indonesia, (Bandung, Tarsito, 1084), h. 143

6 Hilman Hadikusuma, Hukum Perkawinan Indonesia Menurut Perundang-undangan, Hukum Adat dan Hukum Agama.(Badung; Pt Mandar, 2007), h. 9

7 Departemen Pendidikan dan Kebudayaan Kantor wilayah Provinsi Bengkulu, Sending Delapan dan Undang-undang Adat Lembaga Raja Melayu (Bengkulu, Diroktorat Jenderal Kebudayaan, Sejarah dan Nilai Tradisional, 1990), h 54

${ }^{8}$ Talib Setiady, "Intisari Hukum Adat Indonesia: dalam kajian.. Op., Cit h. 230-237

9 Talib Setiady, "Intisari Hukum Adat Indonesia: dalam kajian.... Ibid.,h. 239

${ }^{10}$ Djamanat Samosir, Hukum Adat Indonesia, Eksistensi dalam Dinamika ...Op. Cit, h. 285

11 Departemen Pendidikan dan Kebudayaan Kantor wilayah provinsi

$\begin{array}{lcr}\text { Bengkulu, Adat dan } & \text { Upacara } \\ \text { Perkawinan } & \text { Daerah } & \text { Bengkulu } \\ \text { (Bengkulu, } & \text { Diroktorat } & \text { Jenderal } \\ \text { Kebudayaan, } & \text { Sejarah dan Nilai } \\ \text { Tradisional, 1995), h. 25 } & & \end{array}$

${ }^{12}$ Departemen Pendidikan dan Kebudayaan Kantor Wilayah Provinsi Bengkulu, Sending Delapan dan Undang-Undang Adat Lembaga...Op.. Cit , h 55

${ }^{13}$ Hilman Hadikusuma,. Hukum

Perkawinan Indonesia... Op..Cit. h. 20

${ }^{14}$ Kompilasi Hukum Islam. Pasal 30.

${ }^{15}$ Al Qur'an Surat Al Baqarah; 236

16 Tengku Muhammad Hasbi Ash Shiddieqy "Fiqhul Sunnah" Tth. h. 93

${ }^{17}$ Sayyid Sabiq “Fikih Sunnah",

Juj 3 (Dar Fath Lil ilmi al Arabiy. Jakarata, Cakrawala Publising) : 2011).H. 410-413

${ }^{18}$ Kompilasi Hukum Islam. Pasal 30 sampai pasal 38 .

${ }^{19}$ Al Qur'an Al- Nisa':4 Pemberian itu ialah maskawin yang besar kecilnya ditetapkan atas persetujuan kedua pihak, karena pemberian itu harus dilakukan dengan ikhlas

\section{Bukhari, Bab" Tazawajal} Mu” Asira "Ardhul Marati Nafsihaa. Hadis No 4697 . lihat juga dalam kitab Shohih al Bukhari dan Muslim; Alita Aksa Media: Jakarta 2013. H 377

21 Al Qur'an An Nisa'; 20-21 menceraikan isteri yang tidak disenangi dan kawin dengan isteri yang baru. Sekalipun ia menceraikan isteri yang lama itu bukan tujuan untuk kawin, Namun meminta kembali pemberianpemberian itu tidak dibolehkan

${ }^{22}$ Kata makruf terambil dari kata 'urf dalam bentuk pasif (dikenal) jadi dalam hal memberikan nafkah, pakaian dan perlindungan itu sesuai dengan 
Jurnal Hawa Vol. I No. I Januari-Juni 20IG

kebiasaan atau yang sudah dikenal pada tempat dimana mereka bertempat tinggal. Al Qur'an surat al Baqarah; 233

${ }^{23} \mathrm{Al}$ Qur'an surat at Thalaq ayat 7

${ }^{24} \mathrm{Al}$ Qur'an surat an Nisa' ayat 4

ألَّنسآدِ .....

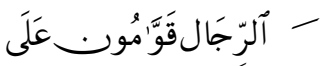

${ }^{25}$ Sayyid Qutub, Fi Zilal al Qur'an, (Beirut: Dar al 'Arabyah, Tth), h. 52

${ }^{26}$ Subekti, R Tjitrosudibio, Kitab Undang-Undang Hukum Perdata, Burgerlijk Wetboek dengan Tambahan Undang-Undang Pokok Agraria dan Undang-Undang Perkawinan, (Jakarta, Pt Pradnya Paramita, 1992) pasal 105106

27 Syayid Sabiq, Fiqh As-Sunnah, Tahkik dan Takhrij oleh Muhammad Nasiruddin al Albani, (Jakarta; Cakrawala, 2011), h. 430

28 Undang-Undang no 1 tahun 1974, tentang perkawinan. Pasal 35- 37 dinyatakan: Harta benda diperoleh selama perkawinan menjadi harta bersama, harta bawaan dari masingmasing suami isteri dan harta yang diperoleh masing-masing sebagai hadiah atau warisan, adalah dibawah penguasaan masing-masing sepanjang para pihak tidak menentukan lain. Mengenai harta bersama suami atau istri dapat bertindak atas persetujuan kedua belah pihak. Mengenai harta bawaang masing-masing, suami dan istri mempunyai hak sepenuhnya untuk melakukan perbuatan mengenai harta bendanya. Biaya perkawinan putus karena perceraian, harta bersama diatur menurut hukumnya masing-masing.
${ }^{29}$ Harta bawaan adalah harta yang di dapat bukan pada saat perkawinan dan bukan yang didapat selama perkawinan. Seperti, harta warisan, hadiah, hibah, dan harta hasil usaha saat sebelum terjadi perkawinan.

30 Menurut hukumnya masingmasing maksudnya adalah bahwa undang-undang ini memberikan peluang pada kedua belah pihak untuk memberlakukan hukum yang dikehendaki dalam rangka mencari penyelesaian pembagian harta bersama mereka.

${ }^{31}$ Kompilasi Hukum Islam pasal

\section{5- 97}

${ }^{32}$ Kompilasi Hukum Islam pasal 96 yang berisikan; apabila terjadi perceraian (mati), maka separuh harta bersama menjadi hak pasangan yang hidup lebih lama. Dan pembagian harta bersama bagi seorang suami atau istri atau suaminya hilang harus ditangguhkan sampai adanya kepastian matinya yang hakiki atau matinya secara hukum atas dasar putusan Pengadilan Agama

33 Kitab Undang-Undang Hukum Perdata (Burgerlijk Wetboek) bab enam tentang persatuan harta kekayaan menurut undang-undang dan pengurusannya, pasal 19, 139 dan 154

${ }^{34}$ Pasal 24 KUHP Perdata. Dalam pasal 40 perjanjian yang demikian tidak boleh mengurangi segala hak yang disandarkan kepada kekuasaan suami sebagai kepala persatuan harta suami dan istri, kecuali namun ini, bahwa berhaklah si istri memperjanjikan bagi dirinya, akan mengatur sendiri urusan harta kekayaannya pribadi, baik bergerak maupun tak bergerak, dan akan meninkmati sendiripula dengan bebas pendapatannya secara pribadi. Dalam Kompilasi Hukum Islam kekuasaan 
suami diatur dalam pasal 89 “ Suami bertanggung jawab menjaga harta bersama, harta istri maupun hartanya sendiri" Pasal 90 "Istri turut bertanggung jawab menjaga harta bersama maupun harta suami yang ada padanya. Pasal 92 "Suami atau istri tanpa persetujuan pihak lain tidak diperbolehkan menjual atau memindahkan harta bersama" dan pasal 93 "pertanggungjawaban terhadap hutang suami atau istri dibebankan pada hartanya masing-masing. Petanggungjawaban terhadap hutang yang dilakukan untuk kepentingan keluarga, dibebabankan kepada harta bersama, bila harta bersama tidak cukup, dibebankan kepada harta suami, dan bila harta suami tidak cukup atau tidak ada dibebankan kepada harta istri.

${ }^{35}$ Abd al Wahab Khallaf, Usul alFiqh, (Jakarta; DDII, 1974), h. 136 dan Abu Zahrah, Ushul al-Fiqh, (Kairo, Dar al Fikr al Arabi, Tth), 319

${ }^{36}$ Pengertian keluarga adalah sanak saudara, kaum kerabat, seisi rumah, ibu bapak, anak-anaknya, orang-orang seisirumah yang menjadi tanggungan, atau satuan kekerabatan yang sangat mendasar. Lihat Departemen Pendidikan dan Kebudayaan, Kamus Besar bahasa Indonesia,(Jakarata; Balai Pustaka. 1988), h. 413 dan W.J.S Poerwadarminta, Kamus Umum Bahasa Indonesia, (Jakarta: Balai Pustaka, 1985), h. 470. Keluarga juga diartikan dua orang atau lebih yang hidup bersama, yang mempunyai hubungan darah, perkawinan atau karena pengangkatan. Bisri Mustofa dan Elisa Vindi Maharani, Kamus Lengkap Sosiologi, (Jogjakarta; Panji Pustaka, 2008), h. 103. Dan dalam Undangundang Nomor 10 Tahun 1992 tentang kependudukan dan Keluarga Sejahtera Bab Ketentuan Umum, menjelaskan bahwa keluarga merupakan unit (Lembaga) terkecil dalam masyarakat yang terdiri dari suami dan istri , atau suami istri dan anaknya, atau ayahnya dengan anaknya, atau ibu dengan ayahnya. Adapun hidup berkeluarga adalah kehidupan bersama dua orang lawan jenis yang bukan mahramnya yang telah mengikatkan diri dengan tali perkawinan beserta anak keturunannya yang dihasilakn dari akibat tersebut. Pengertian keluarga memiliki dua dimensi; pertama, keluarga sebagai ikatan kekerabatan antar individu, ini merujuk pada hubungan darah dan perkawinan. Kedua "rumah tangga" dalam makna ini ikatan kekerabatan amat penting, namun yang menjadi penekanan adalah kesetuhunian dan ekonomi. Sedangkan dalam al Qur'an surat Thaha:132 dan surat al Tahrim: 6, keluarga diistilahkan dengan al Ahlu (Famili, keluarga dan kerabat).

${ }^{37}$ Undang-undang No 1 Tahun 1974 dan Kompilasi Hukum Islam. Pasal 77. Di jelaskan bahwa suami dan istri memikul kewajiban yang luhur untuk menegakkan rumah tangga yang sakinah, mawaddah waraohmah, wajib saling mencintai, saling menghormati, setia dan memberi bantuan lahir dan batin. Keduanya berkewajiban mengasuh, memlihara anak-anak mereka, wajib menjaga kehormatannya.

${ }^{38} \mathrm{Al}$ Qur'an surat an Nisa':34

${ }^{39}$ Kompilasi Hukum Islam pasal 79 ayat 1 dan 2

40 Abdul Wahab Khalaf, Mashadir al Tasyri' Fi ma la Nashshah Fih, (Kuwait: Dar al Qalam, 1983), h. 90 
Jurnal Hawa Vol. I No. I Januari-Juni 20IG

${ }^{41}$.Abdul Walid' ' kumpulan kaidah

Ushul Fiqh' (Jogjakarta; IRCiSoD, 2014), h. $150-151$

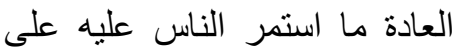

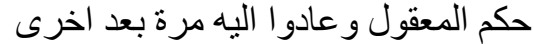

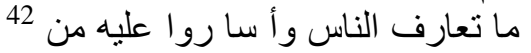

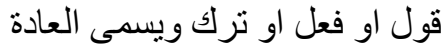

${ }^{43}$ Amir Lutfi", Hukum Perubahan Struktur Kekuasaan; pelaksanaan Hukum Islam dalam kesultanan Melayu Siak,1901-1942, (Pekan Baru; Suska Press, 1991), h. 20

${ }^{44}$ Kitab Hadis 9. Kitab Ahmad.

${ }^{45}$ Abdul Wahab Khalaf, Ilmu Ushul

Fiqh, (Kuwait: Dar ul al Qalam. 1983), h. 89 